\title{
Migrant children in cities: The spatial constructions of their everyday lives
}

Daniela Sime, School of Social Work and Social Policy, University of Strathclyde

daniela.sime@strath.ac.uk

\section{Cite as:}

Sime, D. (2017) Migrant children in cities: The spatial constructions of their everyday lives, in Ni Laoire, C. White, A.; Skelton, T. (eds) Movement, mobilities and journeys, pages 271-288, NY: Springer.

\begin{abstract}
This chapter explores the significance of place in migrant children's lives, with a focus on their experiences in urban areas. We discuss the reconfigured spatiality of children's mobility as a result of their migration and examine how current discourses around socially inclusive cities and children's rights are in contrast with migrant children's everyday experiences of mobility and social participation. The chapter reviews existing child-inclusive research, in order to map out the extent and limits of children's spatial mobility post-migration and illustrate their perspectives on life in the city as a child migrant. By looking at children's views on their experiences of inner city mobility, the review highlights the barriers children are confronted with, their limited opportunities for social networking and civic participation and increased confinement to the domestic space. It also examines the factors which impact on children's restricted mobility, including parents' perceptions of safety, cultural beliefs and limited social networks in facilitating access, and argues that current debates on the role of children's place in cities need to move away from monolithic views of the 'urban child'. The chapter concludes that limited consideration of the different ways in which (adults in) cities restrict migrant children's mobility and a narrow understanding of how children can access opportunities are currently hindering the development of inclusive social policies which reflect fairly children's voice.
\end{abstract}




\section{Introduction}

The concentration of economic and financial powers in large cities has led in recent decades to global trends of mobility from rural to urban areas within and across nations (Vertovec, 2009). The majority of people around the world live now in urban areas, although a quarter of the world's children live in poor urban settlements (Bartlett, 2010). On a global scale, more affordable transportation and telecommunications have facilitated an increase of the extent and impact of global interconnectedness. Urry (2003: 250) talks about globalisation as 'taking the form of multiple, complex, messy proximities and interconnections', with enhanced connections between social groups as one of its key manifestations. Unprecedented levels of global mobility (Castles and Miller, 2009) have generated major social concerns across all receiving countries, such as the nature and effectiveness of social integration of migrants and the social and ethnic segregation in cities. These have become central issues for political and public debate, especially as 15 percent of the world's estimated 232 million migrants are children and young people (European Commission, 2012). As a consequence, over the last few decades, research on the impact of family migration on children and on children's own experiences of migration has flourished. Studies have examined children's role in the family migration processes (Orellana et al., 2001; Bushin, 2009), the impact of migration on children's well-being (Chuang and Moreno, 2011), on their family relationships and friendships (Reynolds, 2004, 2007; Haikkola, 2011; Jugert et al., 2013; Sime and Fox, 2014b), and children's own experiences as migrants (Ní Laoire et al., 2011; Bak and Brömssen, 2010; Sime and Fox, 2014a) or when born into immigrant families (Levitt and Waters, 2002).

Migration causes significant changes in the adult-child power dynamics at family level and discourses about adult migrants' experiences cannot be assumed or transferred to migrant children. Recent calls to examine migrant children's agency rather than rely on adults' accounts are based on the 'competent child' approach to researching their lives, inspired by the new sociology of childhood (James et al., 1998). Children's active role post-migration has been highlighted, for example, in research showing their role as cultural brokers for families (Schaeffer, 2013) or when navigating confidently their families' local and transnational spaces (Devine, 2009, 2011; Ní Laoire et al., 2011). In the context of transnationalism, defined as 'processes, patterns and relations that connect people or projects in different places in the world' (Harney and Baltassar, 2007:190), the experiences of children as migrants and as members of transnational communities is still to be fully understood, although research has started to examine these issues through children's perspective. Studies have explored children's views of their agency in the migration process (Knörr, 2005), their experiences of transnational families (Parreñas, 2005; Punch, 2012; Tyrell et al., 2013), their identity and feelings of belonging (Ní Laoire et al., 2011) and their experiences when migrating unaccompanied by adults (Yaqub, 2007; Crawley, 2009; Hopkins and Hill, 2010). Two special issues in the Journal of Ethnic and Migration Studies (Transnational Migration and Childhood, 2011, issue 37, and Transnational Migration and the Study of Children, 2012, issue 38) have also showcased some of the recent developments in investigating children as active agents in the global political economy. Many of these studies look at children's own 
engagement in places and spaces they access, configuring thus new interests in theorising migration in relation to locality, as well as focussing on children's own views. These current trends in research on childhood and migration clearly see children as active agents in the processes of global migration, with their own experiences and views which need to be explored further.

Migrant children's experiences need however to be seen in the context of adults' views of children as in need of protection and the increased anxieties that a new, unknown place may pose (Olwig and Gulløv, 2003). In the context of intense international debates about approaches to improving quality of life and equity in cities (Fainstein, 2011), the place of children in increasingly segregated urban areas, with the associated inequities in terms of access to resources and opportunities, has become a central issue for research. This has also highlighting the need to document the complex, multidimensional experiences children have themselves as 'citizens in the present'. Urban landscapes are 'landscapes of power' (Matthews et al., 2000a), firstly, through the ways in which spaces are designed and managed by the majority through spatial policies and practices which lead to inner city segregation, and secondly, through the limited control that children have over public spaces. Geographies of childhood have, over the last decade, addressed the issue of children's location in cities and the degree to which they have access to specific places of play, living and learning. Authors have highlighted how public spaces have been claimed by adults (Christensten and O'Brien, 2003), leading increasingly to children's isolation in the home and a discourse that presents urban spaces as increasingly dangerous and young people in the streets as destabilising to the social order. The social construction of childhood is also becoming highly spatialized (Holloway and Valentine, 2000:16), and the inside/outside barriers strongly enforced by adults, restricting thus children's mobility. Research concerning the marginalised youth in urban areas, emphasising the structural inequalities that cities create in relation to race, ethnicity and class has been a productive area of urban and youth studies. Another strand of work has also examined the key role that place plays in children and young people's opportunities for mobility (Reynolds, 2004, 2007) and well-being (McKendrick, 2014). In relation to the significant relation between migration, ethnicity and neighbourhoods, authors (Watt and Stenson, 1998; Sutton and Kemp, 2011) have highlighted the marginalised position of migrants, often seen as undesirables and a threat to local resources (Cook et al., 2012). This evidence has direct implications for the study of migrant children's lives and their opportunities for civic participation and integration, linked also to notions of belonging and identity.

This chapter provides an overview of three key themes which have concerned recent research on migrant children and youth and the spatial constructions of their everyday lives post-migration. Firstly, the issue of mapping out the urban spaces navigated by children post-migration and the factors affecting their inner city mobility is key, to capture children's everyday experiences and provide a better understanding of how being a 'new arrival' in one place limits young migrants' movement and opportunities for social participation. Secondly, the intersection between spaces that children can access or feel they belong to, and relationships negotiated across these, such as at neighbourhood and community level, is fundamental to 
understanding their lives post-migration. The third theme concerns the opportunities that exist for migrant children in cities to be actively engaged in debates about the places they live in and contribute to changing them in the future. While children may be expected to become competent navigators of the urban landscape and demonstrate their agency across a range of settings, such as neighbourhoods, home, school and communities, this chapter examines the extent to which there is a gap between the increasingly popular rhetoric of children's agency and the everyday realities of their, overall restricted, mobility. We show how, in the case of migrant children, opportunities for mobility and civic participation are often constrained by factors such as adults' increased controls, economic and social exclusions and distinct characteristics of the areas in which they live. A significant aspect of young migrants' decisions to fully engage with others is their sense of belonging within their new communities. In this sense, we examine how migrant children's positioning in cities, as intrinsically liminal and marginal due to their 'newcomer' status and other factors such as economic and social deprivation and adults' control, is a key aspect when considering all children's voice in processes of urban change.

\section{Migrant children's marginalisation and social exclusion in cities}

Research on cities has focussed on their inherent structural inequalities, with neighbourhoods polarised into areas of affluence and those affected by marked deprivation, populated by low-income communities and leading to increasing disaffection among young people (MacDonald and Marsh, 2005; Dillabough and Kennelly, 2010). Other authors have also discussed the significance of urban policies and practices which lead to economically and socially segregated neighbourhoods, mainly with a focus on US cities and marginalisation of Latin American and black youth (Deutsch, 2008; Sutton and Kemp, 2011). Around the world, high proportions of ethnic minority groups live in poor neighbourhoods, where poverty leads to other disadvantages, such as substandard housing, low-performing schools and poor services, limited access to healthy foods and adequate leisure spaces, higher rates of crime and vandalism (Fainstein, 2011). The connection between disadvantaged neighbourhoods, ethnic diversity and social cohesion has received significant attention (Cheong et al., 2007). In particular, there has been research and policy interest in interethnic community cohesion and the ways in which are-based initiatives can be successful in tackling social disadvantage for young people and lead to community cohesion (Joseph Rowntree Foundation, 2014). However, there has been much more limited interest in the ways in which children and young people, especially when newly arrived to an area through migration, learn to navigate these socially diverse areas, and the nature of their day-to-day, informal negotiations of ethnic difference alongside issues of social class. Although drawing here on a relatively small number of studies, we seek to contribute to these debates by focussing first on children's everyday negotiations of difference and their experiential ways of 'learning the ways' in their new neighbourhoods. Rather than focus on localities only, we are interested in summarising the evidence on migrant children's 'intensities of everyday social relationships, materialities, sensory experiences, practices, representations, discourses, and more' (Pink, 2012). We are interested in the evidence 
on children's experiences and ongoing negotiations of urban spaces, and also the factors that influence children's mobility and access to opportunities for play, learning, leisure and civic participation.

Evidence suggests that certain groups of migrants can be marginalized not only economically (through insecure work and poor pay), but also socially (through residential segregation, lack of political capital, limited informal networks of support). Bourdieu (2006:3) has talked about disadvantaged 'housing projects' or communities which 'bring together people who have nothing in common and force them to live together, either in mutual ignorance and incomprehension or else in latent or open conflict' (2006:3). Sutton and Kemp (2011) claim that social and economic factors force migrants to share disadvantaged areas with other marginalized social groups and these areas become focus of inter-ethnic conflict. Migrants' limited choice in relation to the areas they live in has been highlighted by other writers (Ryan, 2011; McGhee et al., 2013; Trevena et al., 2013); as they often rely on existing social networks and low-skilled employment in the initial stages, they find themselves forced to share highly populated urban areas, with cheaper accommodation. The everyday tensions inherent in urban areas blighted by social disadvantage, often marked by 'white territorialism' (Hesse et al., 1992: 171) and resentment of new migrants, make social and ethnic mixing more complicated. Webber (1964:147) argued that 'it is interaction, not place, that is the essence of the city and of city life' and in relation to migrant groups, opportunities for social mixing vary, depending on migrants' ability to secure housing in socially mixed areas. Feinstein (2011) discusses the basic principles of a 'just' city, which enables the free movement of children through it. In order to be able to access opportunities available to them, children need to feel safe to navigate the city outwith their immediate locality, have access to information on services available to them and feel welcomed by others. Social mixing has been often advocated as a key to social integration and community cohesion. Nevertheless, socially mixed environments do not necessarily lead to social mixing (Reay et al., 2011). The lack of opportunities for mixed friendships often leads migrants to form closely linked ethnic networks (Bankston, 2004; Reynolds, 2007), which, although supportive on an emotional level, may equally lead to segregation. Portes (1998) talked about the narrow ties within one community which comes together after migration in 'ghettoes' of marginalisation, which limits people's ability to access existing resources and use these to improve their social position.

The material resources available to children post-migration vary markedly, depending primarily on parents' employment, which leads to variations in aspects such as children's type of housing, quality of schools, access to good quality health services and leisure spaces. Evidence exists that services are of a higher quality in affluent areas, attracting more affluent families, while deprived neighbourhoods become the last resort for poorer migrants (McGhee et al., 2013). Research with adults shows that migrants make low use of health and leisure services (Spencer et al., 2007), due to factors such as the language barrier, lack of information and poor access (Arai, 2006; Sime, 2014). In relation to migrant children, evidence suggests that a hostile urban landscape dominated by physical decline, perceived risks from others and traffic and inaccessible local services lead many to a retreat to the indoors post-migration. The relationships between the nature of public spaces, services available locally and children's play and social networks suggests that particular 
features of neighbourhoods are crucial to generating opportunities for children's participation and social integration. Putnam (2000) argues that individuals' participation in associational activities, such as clubs and sports activities, contributes to social cohesion and facilitates the creation of social capital. In the case of migrant children, participation in activities within the community is also an opportunity to engage in bridging or forging of 'weak ties', which may allow them better access to valuable resources outwith the area. However, networks of access to resources are built in ways that privilege some 'insiders' (i.e. the established communities) over the 'outsiders' (Ryan, 2011). In the context of variable policies of restrictions of migrants' rights and diversity, migrants are often uncertain on their entitlement to access services and unsure on how the systems operate. Additionally, due to perceived neighbourhood risks, migrant children's access to local resources is often restricted by their parents, as the following extracts from the author's show (Sime and Fox, 2014a):

Because of the area we live in, there are many teenagers who take drugs, drink and smoke in the local park, and sometimes shout things like, stupid, fucking Polish when you pass by, so there is no way I would let Bartek out to play or walk by himself to the library. (Agata, Polish mother)

We live quite far from everything, plus my mum says my English is not good enough yet, she says I might get attacked and things, so I tend to stay mostly at home. (Radicz, Lithuanian, age 13)

Although local neighbourhoods are often seen as spaces of networking possibilities, issues of ethnic discrimination and perceived risks are often barriers to migrant children's opportunities to develop friendships with local children and participate in local activities. Empirical studies have also evidenced the powerful relationship between class and educational differences and cultural behaviour among migrant groups (Lopez-Rodriguez, 2010; Neal and Vincent, 2013). Engagement with cultural and leisure activities can create opportunities for newly arrived children to 'bridge' networks and participate in develop a sense of belonging and experience their neighbourhoods, highlighting the significance of making places for leisure accessible locally. In our study (Sime and Fox, 2014a), which examined Eastern European migrant children's access to services, in addition to the nature of the places migrants lived in, children's engagement with services was hindered by other barriers, such as their limited knowledge of services they were entitled to, language barriers and fear of travelling alone and perceived negative attitudes of staff. Children often said that their confinement to the indoors post-migration was less a matter of choice and more a matter of parental decision to keep them safe.

However, children should not be seen as passive receivers of their parents' decisions and their active role in socially connecting their families and brokering access to services and places for other family members needs to be acknowledged and further documented (see Schaeffer, 2013; Sime and Fox, 2014b). Children's agency, within the context of what local places have to offer, further illuminates the dynamic and ever changing engagement of children in the urban life, and factors such as children's age, gender, length of stay, social class, families' cultural beliefs and parenting styles are all key aspects to consider when examining children's public lives. Nevertheless, the evidence presented in this section clearly maps out the social 
inequalities inherent in cities and calls for more evidence on documenting not only how migrant children see themselves and the neighbourhoods they live in, but also for identifying ways of making cities more accessible and fair to newly arrived migrant children.

\section{A sense of place: Migrant children's perspectives on their neighbourhoods as sites of socialisation and belonging}

There is growing interest in streets and neighbourhoods as spaces of 'routine encounters of difference' (Neal \& Vincent, 2013). By examining the factors which impact on children's spatial mobility in cities, this section sheds further light on the opportunities that migrant children have to form new social networks in their local areas, and the degree to which differences in children's social and/or cultural backgrounds shape and affect these opportunities. Furthermore, through reflecting on children's accounts, we document the mechanisms through which migrant children initiate, maintain and avoid relationships with those who are 'different' to themselves. We are also interested here in reviewing the evidence on the nature and extent to which migrant children and their parents utilize their everyday encounters with 'others' in the neighbourhoods to diversify their social networks and use these as sources of access to opportunities for social participation.

In the case of migrants, belonging and social inclusion are closely connected (Anthias, 2011), as experiences of social participation lead to a sense of a stake in society and acceptance. Studies on the intersection between social class and ethnicity (Archer, 2011; Ball et al., 2011; Neal and Vincent, 2013) have showed the class separations in socially diverse urban localities and the polarisations within ethnic groups, with the emergence of more affluent ethnic minority middle classes. Attributes of social class and the characteristics of the neighbourhoods in which migrants live (Devine, 2011; McGhee et al., 2013) influence the opportunities that migrant children have to build advantageous social networks and develop their sense of belonging. Schools are seen by children as important sites of socialisation and development of peer networks (Bak and Brömssen, 2010; Devine, 2009). Dustmann et al. (2010) have found however that ethnic minority children in Britain attended different schools from White British pupils, with clear evidence of ethnic segregation; while the average share of White British classmates for pupils who were White British themselves was of $93 \%$, it was only $33.4 \%$ for Pakistani pupils. In more socially mixed schools, teachers often encouraged children to develop friendships with children of the same ethnicity, reflecting teachers' a-critical approach to working with diverse learners (Devine, 2011). Others have showed how young migrants may be identified by teachers as 'a problem' that consumes valuable resources and pose a threat to the host society (Suárez-Orozco et al., 2011) and how their cultural capital may be devalued by schools (Leopold and Shavit, 2013; Moskal, 2014). Research has also focussed on the underachievement of migrant youth, especially in relation to 'black-white gap in school achievements' (Tomlinson, 2003). The achievement gap has been shown to be highest for first generation migrants (OECD, 2012 a,b) and rates of early school leaving are double for migrant youth compared with indigenous children (OECD, 2011). 
Research also shows that migrant children arriving at secondary school age are particularly at risk of underachievement and social exclusion (OECD, 2012 a,b). Odé (2002) has argued that the educational level is the dominant explanatory variable of socio-economic and cultural integration and education is a highly important mobility channel. Nevertheless, evidence on the links between area deprivation and underachievement clearly point to the significance of place in the quality of children's educational opportunities. Educational policies tackling social segregation by engineering social mixing have been shown to have minimal impact, as young people from different social backgrounds are separated in schools and communities through their own patterns of identification and disidentification (Reay, 2007). With social stratifications by neighbourhoods segregated mainly on the basis of affluence, ethnicity and social class, opportunities for inter-ethnic friendships and social mobility remain minimal for migrant youth from poorer backgrounds. Devine (2011) also shows how parents' positioning in relation to their children's schools will be influenced by the capitals they bring to the interaction and also by how other parents and teachers interact with them- these patterns of interaction are often 'classed, racialized and gendered' (Devine, 2011: 111), which makes schools sites which can perpetuate segregation rather than tackle it.

Researchers have also turned their attention to the street as a site of socialisation and social relationships and despite modern day moral panics about 'the stranger dancer' and perceptions of risks, many children say that street play and socialisation is part of their daily routine (Penn and Lambert, 2009). Several factors have been identified as directly significant in relation to children's independence in cities. Aspects such as perceived safety and risks (Watt and Stevenson, 1998; Matthews, 2003), design of public spaces and limited access to good quality services (Dillabough and Kennelly, 2010) and adults' control (Sime and Fox, 2014a) have all been mentioned in relation to children's independent access to public sites of socialisation. In addition, cultural beliefs and values, such as those linked to gender, have also been reported. In a study on children's independent mobility with over 1000 children in inner London, O'Brien et al. (2003) reported that older Asian girls were particularly absent from the public realm, with only 37 percent of them allowed to play out unaccompanied in contrast to 92 percent of the Asian boys from the same neighbourhood. In our study of Eastern European migrants (Sime and Fox, 2014 b), children often thought that parents were less restrictive with boys when it came to playing outside or walking alone to local places, such as parks or libraries.

The value of intra-ethnic and inter-ethnic networks and friendship groups as a mechanism for developing a sense of belonging and for facilitating access to resources has also been explored by research. While in the initial stages post-migration, children employ complex strategies to maintain transnational friendships (Haikkola, 2011), including using technologies to keep in touch and visiting friends during occasional trips to their homeland, these relationships fade over time due to lack of regular contact. New friendships are however not straight forward (Aboud et al., 2003; Sime and Fox, 2014 b), and migrant children experience contradictory feelings of excitement and anxiety, self-determination and self-protection, initiative and helplessness when it comes to making new friends. Friendship networks have been shown to fulfil various positive functions for children and young people (Hill, 2002), including access to wider, capital-forming 
networks. However, the nature, strength of ties and dynamics of friendship networks varies considerably between children, and depend on factors such as age, gender, social class and children's resourcefulness in initiating and maintaining social networks. Friendships are key to children's overall satisfaction with their migratory experience and often provide key ties for accessing local resources. In our study of Eastern European children in Scotland, children talked about accessing services together with their Scottish and other minority friends who knew the area better. Children's resourcefulness in establishing friendships was also demonstrated in the diverse range of settings where new friendships were formed, often involving different levels of closeness and different network benefits. Marta, a Polish girl aged 11, who was living in Scotland for two years, explained how her friendship networks were mapped across contexts:

Marta: My best friend is Weronika, she lives in Poland.

Interviewer: Do you stay in touch?

Marta: Yes, by email or Skype, although we don't speak that often.

Interviewer: In the diary, you wrote that your other friends are Agnieszka, Dominika, Laura, Mika. Marta: Laura is from Scotland and Mika is from Philippines, they are my friends from class, we do homework together, and Agnieszka and Dominika are from Poland, but they live in Scotland and they go to Saturday school, so we talk about Polish things together. And Sylwia, she is friend from my street.

Marta's example illustrates the dynamic and multi-sited nature of children's friendships, many of which bridged over aspects of difference (Juggert et al., 2013), such as ethnicity or social class, and often bonded over gender as the main attribute. While inter-ethnic friendships seemed to enhance children's knowledge of the local language and possibilities for involvement in local activities, intra-ethnic friendships, with children from the same nationality, were often cited as significant to children's happiness and sense of identity. While the assumption is often that children's shared language will immediately lead to bonding and friendships, migrant children often say that being from the same country is not enough to generate close relationships, due to markers such as social class or different interests (Sime and Fox, 2014 b). Evidence also exists on parents' efforts to encourage children's intra-ethnic networks through participation in diaspora events, in places such as complementary schools and churches. While these are often seen by parents as important spaces for children to experience cultural-specific norms and build friendships, they are not always the children's choice, reflecting once more the active role of children in developing their own sense of belonging and identity.

The evidence in this section highlights the need for a more nuanced approach to the analysis of children's networks post-migration, by taking into consideration children's multiple cultural frameworks which influence their networking decisions. Migrant children seem to draw upon a combination of inter-ethnic and intra-ethnic networks post-migration, often for different purposes. The opportunities for social networking are however configured by the places in which children live and this highlights the need to re- 
examine neighbourhoods for their potential to offer spaces for socialisation and active participation. There is concern that children in cities, and in particular migrant children recently arrived to an area, are faced with hostile urban landscapes, dominated by derelict or risky public spaces, inaccessible or poor services and threats from others, factors which all contribute to limiting children's independent mobility and ultimately, their sense of belonging.

\section{Migrant children's opportunities for social participation: A matter of children's rights}

The participation of children and young people in decision-making processes is a relatively new phenomenon, arguably triggered by the United Nations Convention on the Rights of the Child (1989). Article 12 of the convention clearly states that children and young people should have their opinions taken into account in all major decisions affecting their rights. Some have argued that the most significant change brought by the convention is the way in which children have become 'visible' and the fact that the broader civil society feel compelled to include children in any interventions and debates (Van Beers et al., 2006). Nevertheless, Hart (2009) argues that children's participation in decision making with adults or through consultation is a narrow view of children's participation through citizenship and although giving them a voice, it does not address their participation in civil society. While the case for listening to children and young people's views has been made and research and policy acknowledge children's agency, evidence from research suggests that children and young people mainly feel marginalised in communities. In relation to migrant children, the evidence summarised in this chapter shows the diverse social contexts in which they live their lives and the considerable impact that adults' everyday attitudes and practices affect their opportunities for genuine participation and involvement in community.

Authors have spoken against a tokenistic approach of consultations with children and young people, when these are taking place. Morrow (2006) emphasises the importance of acting on children's recommendations, while taking into account the particular contexts of their participation and the different characteristics of children in terms of gender, social class, dis/ability, ethnicity, religion, sexual orientation and previous experiences of participation. As with adults, participation in consultation and community events seems to attract mainly articulated, well-educated and usually middle-class young people. This can often lead to a sense of unrepresentativeness of consultations, limited voice and sense of marginalisation, and result in spaces and services which do not meet young people's needs.

In order to increase opportunities for social participation in relation to migrant children in cities, education services, local planning and decision making bodies need to listen to migrant children's experiences and ideas on innovation in existing services designed for majority, mono-cultural populations, and identify ways of increasing their autonomy and mobility. This implies identifying better mechanisms for their effective inclusion in consultations on urban designs, modernisation of public spaces and services and how cities can become 'fairer' and child-friendly. Evidence from research suggests that migrant children, although more 
and more visible in cities, are paradoxically invisible in terms of service delivery and policy, although research has documented the needs of migrant young people in cities from their perspective. When asked, migrant young people refer to the poor availability of services in the local areas, linguistic and cultural barriers in accessing these, negative attitudes of staff who deliver these services, run down local areas and fears over their safety. These findings highlight the importance of revising service provision in areas which have become more multi-cultural through migration in recent years and address urban community dynamics. A prominent theme that emerges from research is the significance of community attitudes towards migrants. This often leads child migrants to isolate themselves in the home for fears over their safety, especially when living in run-down or deprived areas, and leads migrant parents to restricting their children's independent mobility. Recognising the power differentials between different groups at community levels (between different groups of adults, different groups of children, and between adults and children) and identifying ways in which inter-generational and inter-ethnic tensions may lead to marginalisation or self-exclusion of migrants is key to identifying community-based solutions, in order to increase migrant children's opportunities for genuine inclusion and civic participation.

\section{Conclusion: Towards fairer cities for migrant children}

The evidence presented in this chapter has shown the marginality of migrant children in cities. The emphasis that recent social policies have placed on social mixing has not always translated into community cohesion and supportive environments for newly arrived migrants. While policies need to identify more positive participatory ways to bridge generations and cultural groups in communities, debates on the role of children and young people's place in cities need also to move away from monolithic views of the 'urban child'. The studies to date on migrant children's experiences have shown the multitude of the ways in which children routinely navigate the urban spaces in which they find themselves post-migration and how they continuously develop their competency in engaging with others in opportunities for social participation. However, questions as to whether they have genuine opportunities for social inclusion and participation still remain. The inherent, multiple ways in which (adults in) cities restrict migrant children's mobility and a narrow understanding on how children can access opportunities and take an active role in improving urban landscapes are currently hindering the development of inclusive social policies which reflect fairly minority children's voice. Their experiences of 'difference' and marginality are experienced in a range of settings, at home, school and in their neighbourhoods, through everyday encounters with others and the social and affective practices of structural exclusion.

Currently, limited consideration of the different ways in which (adults in) cities restrict migrant children's mobility and a narrow understanding of how children newly arrived in a city face barriers in their everyday practices of accessing opportunities are hindering the development of inclusive social policies which reflect fairly children's voice. Equally, current discourses around socially inclusive cities are in contrast with 
migrant children's everyday experiences of independent mobility and genuine social participation. This means that social policies of urban planning and service improvement need to consider novel ways of enhancing young people's participation and engage more meaningfully with new migrants as a matter of course. There can be no doubt that better provision of services for migrant children, improved access to local opportunities for social engagement and increased participation of migrant children in designing urban landscapes and improving existing services are key aspects of any future actions of social planning and increased community cohesion in cities.

\section{References}

Aboud, F.; Mendelson, M. and Purdy, K. (2003) Cross-race peer relations and friendship quality, International Journal of Behavioural Development, 27(2), 165-173.

Anthias, F. 2007. Ethnic ties: Social capital and the question of mobilisability, The Sociological Review, 55:4, pp. $788-805$.

Arai, L. 2006. Migrants and public services in the UK: A review of the recent literature, Oxford: Centre on Migration, Policy and Society (COMPAS).

Archer, L. (2011) Constructing minority ethnic middle-class identity: an exploratory study with parents, pupils and young peofessionals, Sociology, 45(1), 134-151.

Bak, M. and Brömssen, K.V. (2010) Interrogating childhood and diaspora through the voices of children in Sweden, Childhood, 17 (1), 113-128.

Ball, S.; Rollock, N.; Vincent, C. and Gillborn, D. (2011) Social mix, schooling and intersectionality: Identity and risk for black middle class families, Research Papers in Education.

Bankston, C. (2004) Social capital, cultural values, immigration and academic achievement: The host country values and contradictory consequences, Sociology of Education, 77 (2), 176-179.

Barlett, S. (2010) Children living in urban poverty: A global emergency, a low priority, in Moreno, T. (ed) Young children in cities: Challenges and opportunities, Bernard van Leer Foundation, Available at: http://www.bernardvanleer.org/Young-children-in-cities-Challenges-and-opportunities

Bourdieu, P. (2006) The weight of the world: Social suffering in contemporary society, $3^{\text {rd }}$ ed., Oxford: Blackwell.

Bushin, N. 2009. Researching Family Migration Decision-Making: A Children-in-Families Approach. Population, Space and Place, 15, 429-443.

Castles, S. and Miller, M. (2009) The age of migration: International population movements in the modern world, $5^{\text {th }}$ edition, Basingstoke: Palgrave Macmillan.

Cheong, P. H., Edwards, R., Goulbourne, H., \& , \& Solomos, J. (2007). 'Immigration, social cohesion and social capital: A critical review'. Critical Social Policy, 27(1), 24-49.

Christensen, P. and O'Brien, M. (2003) Children in the city: Home, neighbourbood and community, Routledge Falmer. 
Cook, J.; Dwyer, P. and Waite, L. (2012) Accession 8 migration and the proactive and defensive engagement of social citizenship, Journal of Social Policy, 41 (2), 329-347.

Chuang, S. and Moreno, R.P. (eds) (2011) Immigrant children: Change, adaptation and cultural transformation, Maryland: Lexinton Books.

Crawley, H. (2009) 'No one gives you a chance to say what you are thinking': finding space for children's agency in the UK asylum system, Area, 42 (2), 162-169.

Dillabough, J. and Kennelly, J. (2010). Lost youth in the global city: Class, culture and the global imaginary. New York: Routledge Falmer.

Devine, D. (2009) Mobilising capitals? Migrant children's negotiations of their everyday lives in the primary school, British Journal of Sociology of Education, 30 (5), 521-535.

Devine, D. (2011) Immigration and schooling in the republic of Ireland: Making a difference?, Manchester: Manchester University Press.

Deutsch, N.L. (2008) Pride in the project: Teens building identities in urban contexts, New York: New York University Press.

Dustmass, C.; Machin, S. and Scönberg, U. (2020) Ethnicity and educational achievement in compulsory schooling, The Economic Journal, 120, 272-297.

Fainstein, (2011) The Just City, Cornell University Press.

Haikkola, L. (2011) 'Making Connections: Second Generation Children and the Trasnational Field of Relations', Journal of Ethnic and Migration Studies, 37(8), 1201-1217.

Harney, N.D. and Baldassar , L. (2007) Tracking transnationalism: Migrancy and its futures, Journal of Ethnic and Migration Studies, 33(2), 189-198.

Hart, R. (2009) Charting change in the participatory settings of childhood, in Thomas, N. (ed.) Children, politics and communication: Participation at the margins, Polity Press.

Hesse, B.; Rai, D.K.; Bennett, C. and McGilchrist, P. (1992) Beneath the surface: Racial harassment, Aldershot: Avenbury.

Hill, M. (2002) Network assessments and diagrams: A flexible friend for social work practice and education, Journal of Social Work, 2(2), 233-254.

Hopkins, P. and Hill, M. (2010) The needs and strengths of unaccompanied asylum-seeking children and young people in Scotland, Child and Family Social Work, 15(4), 399-408.

Joseph Rowntree Foundation (2014) Reducing poverty in the UK: A collection of evidence reviews, York: JRF.

Jugert, P.; Noack, P. and Rutland, A. (2013) Children's cross-ethnic friendships: Why are they less stable than same-ethnic friendships?, European Journal of Developmental Psychology, 10 (6), 649-662.

Knörr, J. (2005) Childhood and migration: From experience to agency, Transaction Publishers.

Levitt, P. and Waters, M. (2002) The changing face of home: The transnational lives of second generation, New York, NY: Russell Sage Foundation.

Leopold, L. and Shavit, Y. (2013) Cultural capital does not travel well: Immigrants, natives and achievement in Israeli schools, European Sociological Review, 29 (3), 450-463. 
Lopez-Rodriguez, M. (2010) Migration and the quest for normalcy: Polish migrant mothers and the quest for meritocratic opportunities in the UK, Social Identities, 16(3), 339-358.

Matthews, H.; H.; Limb, M. and Taylor, M. (2000a) Reclaiming the street: the discourse of curfew, Environment and Planning, 31 (10), 1713-1730.

Matthews, H.; Taylor, M.; Percy-Smith, B. and Limb, M. (2000b) 'The unacceptable flaneur: the shopping mall as a teenage hangout', Childhood, 7(3), 279-294.

MacDonald, R. and Marsh, J. (2005) Disconnected Youth? Growing up in Britain's poor neighbourbood, Hampshire: Palgrave MacMillan.

McGhee, D., Heath, S. and Trevena, P. (2013) Post-accession Polish migrants - their experiences of living in 'low-demand' social housing areas in Glasgow. Environment and Planning A, 45, (2), 329-343.

McKendrick, J. (2004) Geographies of Children's Well-being: In, Of and For Place, Springer collection, Volume?

Morrow, V. (2006) Social capital: A Flawed concept, in Van Beers et al. (2006) Beyond Article 12: Essential Readings in Children's Participation, Bangkok: Black on White Publications- Knowing Children.

Moskal, M. (2014) Language and cultural capital in school experience of Polish children in Scotland, Race, Ethnicity and Education.

Neal, S. and Vincent, C. (2013) Multiculture, middle class competencies and friendship practices in superdiverse geographies, Social \& Cultural Geography, 14 (8), 909-929.

Ní Laoire, C.; Carpena-Méndez, F.; Tyrrell, N. and White, A. (2011) Childhood and Migration in Europe: Portraits of Mobility, Identity and Belonging in Contemporary Ireland, Farnham: Ashgate.

OECD (2011) Equity and quality in education: Supporting disadvantaged students and schools, Paris: OECD Publishing, Available at: http://www.oecd.org/education/school/50293148.pdf

OECD (2012a) Untapped Skills: Realising the potential of immigrant students, Paris: OECD Publishing.

OECD, 2012b. PISA 2009 Technical Report, Paris: OECD Publishing.

Olwig, K.F. and Gulløv, E. (eds.) (2003) Children's places: Cross-cultural perspectives, London: Routledge.

Orellana, M. F., Thorne, B., Lam, W. S. E., \& Chee, A. (2001). 'Transnational childhoods: The participation of children in processes of family migration'. Social Problems, 48(4), 572-591.

Parreñas, R.S. (2005) Children of Global Migration: Transnational Families and Gendered Woes. Standford: Standford University Press.

Penn, R. and Lambert, P. (2009) Children of international migrants in Europe: Comparative perspectives, Hampshire: Palgreave Macmillan.

Pink, S. (2012) Situating everyday life, London: Sage.

Portes, A. (1998) Social capital: Its origins and applications in modern Sociology, Annual Review of Sociology, 24, $1-24$.

Punch, S. (2012). Studying Transnational Children: A Multi-sited, Longitudinal, Ethnographic Approach, Journal of Ethnic and Migration Studies, 38 (6), 1007-1023.

Reay, Diane (2007). 'Unruly Places': Inner-city Comprehensives, Middle-Class Imaginaries and WorkingClass Children, Urban Studies, 44(7), 1191-1201 
Reay, D.; Crozier, J. and James, D. (2011) White middle class identities and urban schooling, Basingstoke: Palgrave Macmillan.

Reynolds, T. (2004). Caribbean families, social capital and young people's diasporic identities. London: South Bank University.

Reynolds, T. (2007). 'Friendship networks, social capital and ethnic identity: Researching the perspectives of Caribbean Young People in Britain'. Journal of Youth Studies, 10(4): 383-398.

Ryan, L. (2011) Migrants' social networks and weak ties: accessing resources and constructing relationships post-migration, The Sociological Review, 59(4), 708-724.

Schaeffer, M. (2013) Inter-Ethnic neighbourhood acquaintances of migrants and natives in Germany: On the brokering roles of inter-ethnic partners and children, Ethnic and Migration Studies, 39(8), 12191240.

Skelton, T. and Valentine, G. (1998) Cool places: Geographies of Youth Cultures, London: Routledge.

Sime, D. (2014) 'I think that Polish doctors are better': Newly arrived migrant children and their parents' experiences with and views of health services in Scotland, Health \& Place, DOI: 10.1016/j.healthplace.2014.08.006.

Sime, D. and Fox, R. (2014a) Migrant children, social capital and access to public services: Transitions, negotiations and complex agencies, Children \& Society, DOI: 10.1111/chso.12092.

Sime, D. and Fox, R. (2014b) Eastern European children's family and peer relationships after migration, Childhood, DOI: 10.1177/0907568214543199.

Spencer, S., Ruhs, M., Anderson, B., \& Rogaly, B. (2007). Migrants' lives beyond the workplace: The experiences of Central and East Europeans in the UK. Joseph Rowntree Foundation, York, UK.

Sutton, S.E. and Kemp, S.P. (2011) The paradox of Urban Space: Inequality and Transformation in Marginalised Communities, New York: Palgrave MacMillan.

Suárez-Orozco, M.M.; Darbes, T.; Dias, I. and Sutin, M. (2011) Migration and schooling, Annual Review of Anthropology, 40, 311-328.

Tomlinson, M. (2003) Lifestyle and social class, European Sociological Review, 19, 97-111.

Trevena, P., McGhee, D. and Heath, S. (2013) Location, location? A critical examination of patterns and determinants of internal mobility among post-accession Polish migrants in the UK. Population Space and Place, 19, (6), 671-687.

Tyrell, N.; White, A.; Ni Laoire, C. and Carpena-Mendez, F. (2013) Transnational migration and childhood, London: Routledge.

Yaqub, S. (2007) Migrant Unaccompanied or Separated Children: Issues and Knowledge Gaps, Florence: UNICEF Innocenti Research Centre.

Urry, J. (2003) Global complexities, International Studies Review, 5, 250-252.

Watt, P. and Stenson, K. (1998) The Street: 'It's a bit dodgy around here' Safety, danger, ethnicity and young people's use of public space, in Skelton, T. and Valentine, G. (1998) Cool places: Geographies of Youth Cultures, London: Routledge, pages 249-265. 
Webber, M.M. (1964) Explorations into urban structure, Philadelphia: University of Philadelphia Press, pp.143164.

Van Beers, H. Invernizzi, A. and Milne, B. (2006) Beyond Article 12: Essential Readings in Children's Participation, Bangkok: Black on White Publications- Knowing Children.

Vertovec, S. (2009) Transnationalism, London: Routledge. 